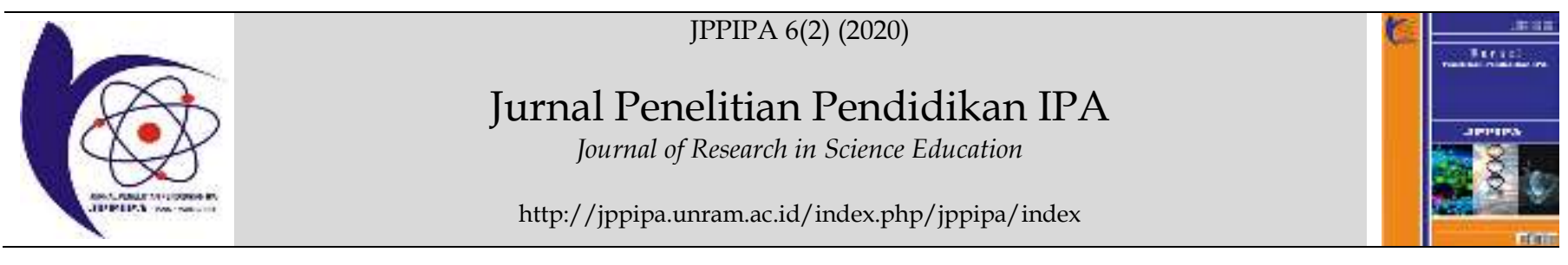

\title{
Development of Interactive Electronic Student Worksheets on Electromagnetic Induction Based on Scientific Approaches
}

\author{
Rita Asma ${ }^{1}$, Asrial $^{1}$, Maison ${ }^{1 *}$ \\ ${ }^{1}$ Master of Science Education Program, Universitas Jambi, Jambi, Indonesia.
}

DOI: $\underline{10.29303 / \text { ippipa.v6i2.387 }}$

\section{Article Info}

Received : January $11^{\text {th }}, 2020$

Revised : May 21th 2020

Accepted: June $4^{\text {th }}, 2020$

\begin{abstract}
This study aims to develop an interactive electronic student worksheet (eWS) on electromagnetic induction material with a scientific approach using 3D PageFlip, Camtasia Studio 8, and Adobe Flash Professional CS6. The research design used is a research \& development design with instructional design procedures that refer to the ADDIE stage as a fundamental process in developing learning resources. The revision process is carried out through formative revisions based on data obtained from an individual, small group, and field trials. The results of the validator assessment of the validity of electronic student worksheet products were analyzed with the Cohen's Kappa formula and obtained k $=1.00$ (valid) for the material and $k=0.89$ (valid) for the media. The implementation of eWS to 177 students and Level 1 evaluations showed that students had a good perception of the content and the media of eWS. They also perceive that they are involved or participate in learning using eWS. An independent-sample t-test was conducted in Level 2 evaluation to compare student learning outcomes. There are significant difference in score for students using eWS $(\mathrm{M}=73.87, \mathrm{SD}=22.56)$ and without $\mathrm{eWS}(\mathrm{M}=27.73, \mathrm{SD}=15.51)$; $\mathrm{t}(54)=10.51$, $\mathrm{p}=0.00$ (two-tailed). The difference in the mean value of $46(95 \%$ confidence level) is large (eta squared $=0.58)$.
\end{abstract}

Keywords: Development; electronic student worksheet; electromagnetic induction.

Citation: $\quad$ Asma, R., Asrial., Maison. (2020). Development of Interactive Electronic Student Worksheets on Electromagnetic Induction Based on Scientific Approaches. Jurnal Penelitian Pendidikan IPA (JPPIPA), 6(2), 136-143. doi: 10.29303/jppipa.v6i2.387

\section{Introduction}

Graduates of each education unit must have competencies in three domains, namely attitude (responsible, honest, and caring), knowledge (factual, conceptual, procedural, and metacognitive), and skills (creative, critical, independent, and communicative). Some research results show that student competence is still relatively low, for example in reasoning ability (Utama, et al., 2018), mathematical representation ability (Fatri, et al., 2019), science process skills (Maison, et al., 2019), and attitudes towards subjects (Maison, et al., 2018). Therefore, physics learning must be designed in such a way that it can contribute to building student competencies in all three dimensions.
Achievement of competencies through the teaching and learning process in the classroom often faces obstacles caused by many factors, for example, the learning environment (Maison, et al., 2019), not yet the maximum implementation of practicum and the use of student worksheets (Hidayati, et al., 2019; Maison, et al., 2019) and the misconceptions experienced by students (Maison, et al., 2020). Building better student understanding can be done with various efforts, such as using multi representations in the learning process (Doyan, et al., 2018). In the 2013 curriculum and modern pedagogic science, the learning process is recommended using a scientific approach. The use of this approach as a whole in learning includes several processes in the form of observing, asking, gathering

\footnotetext{
*Email: maison@unja.ac.id
} 
information, associating, and communicating. The process can be carried out several times as needed; for example, in the initial activities, there is a process of observing physical phenomena through demonstration activities aimed at raising problems. At the core activity, there is another observing process that aims to gather information or data through experimental activities. Ideally, teachers must be able to adjust and maximize the use of the scientific approach in each learning process that is carried out so that there is an interaction between students and various learning resources. Learning physics becomes meaningless, boring, or even considered a difficult activity, especially if the learning process is carried out without maximum interaction with learning resources and media. Oon (2011) found that students became less interested in learning physics because they considered physics relatively difficult and had many abstract concepts for students. The same thing was also found in high school students in the city of Jambi, Indonesia. Based on interviews conducted with several teachers who are members of the Senior High School Physics Teachers Meeting in the City of Jambi Indonesia, it was revealed several problems experienced by teachers in teaching students. These problems include the lack of learning resources, teaching materials, and media for learning physics, especially on electromagnetic induction materials that are interactive, which can be used by students and teachers. One effort that can be done to solve some of the problems above is by designing teaching materials and appropriate electromagnetic induction learning media that can be used through learning based on a scientific approach. There are several forms of teaching materials, for example, modules, books, and student worksheets. When compared with books, student worksheets are complete teaching material because they contain study instructions, supporting information, and work steps. Worksheets can be designed so that the learning process becomes interactive and accommodates every element in the scientific process. Teachers with creativity and innovation can be developed teaching materials in the form of electronic student worksheets (eSW) that integrate various learning media such as videos, simulation media, images. Hidayatullah (2016) has developed FlipBook Maker based learning media on electronic material (semiconductor as a rectifier and Zener diode as a voltage stabilizer), which is used as teaching material in vocational high schools. Based on the results of research conducted by the instructional media proven effective in the use of electronics learning. Furthermore, Kurniawati, et al. (2016) has developed a learning media based on 3D PageFlip physics for vibration, wave, and sound material. In addition to developing the learning media above, some researchers have also developed worksheets for laboratory activities (for example, Hidayati et al., 2019; Khaira, et al., 2017; and Mayasari, et al., 2015). The worksheets developed were on fluid material for high schools (Mayasari et al., 2015), electricity for vocational high schools (Khaira et al., 2017), and curvilinear movements for high school (Hidayati et al., 2019). All research products are categorized as valid and can be used to improve the process and learning outcomes. In this study, an interactive worksheet was developed for high school students with a scientific approach to electromagnetic induction material using 3D Software PageFlip Professional, Camtasia Studio 8, and Adobe Professional Flash CS6. The worksheet developed was on electromagnetic induction material, which was packaged in interactive electronic teaching material. 3D PageFlip Professional software is used to develop the eWS product as a whole. Camtasia Studio 8 software is used to develop some media in the form of video that is needed to fill the worksheet content of eWS that is developed. While Adobe Professional Flash 6 is used to make pages or spreadsheets as well as questions that are more interactive with students.

\section{Method}

Design research and development has been carried out to develop a product in the form of an electromagnetic induction interactive worksheet. The learning design procedure used refers to ADDIE as a fundamental process in developing effective learning resources (Branch, 2009). Figure 1 shows the ADDIE concept (Analyze, Design, Develop, Implement, and Evaluate).

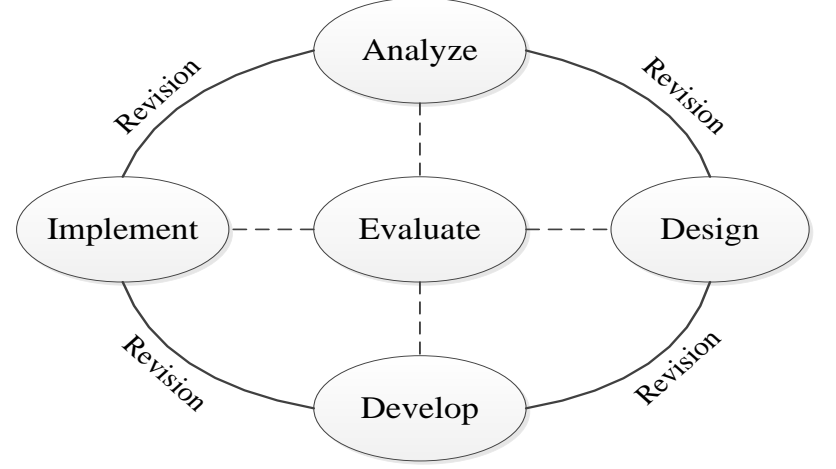

Figure 1. ADDIE concept

The Analyze phase aims to identify possible causes of performance gaps that occur specifically in students. The procedures performed in the analysis phase are (1) validating performance gaps, (2) determining learning objectives, (3) analyzing learners, (4) examining available resources, and (5) determining delivery systems, and (6) making plans work. After the completion of the analysis phase, it is hoped that researchers will be able to determine whether or not to 
fill or close existing gaps, determine the level of learning, and recommend solution strategies to close the gap based on empirical evidence that allows for success. The design phase aims to verify the desired performance and suitable testing methods. The procedures performed are (1) carrying out an inventory of tasks, (2) determining performance goals, (3) determining testing strategies, and (4) calculating investment costs (Branch, 2009). The final procedure of this design stage is to calculate the return on investment not carried out on the development of this worksheet. The development phase aims to produce and validate the worksheets that have been selected for development. The result of this phase is the production of a set of worksheets. The procedures performed at this developing stage are (1) producing content, (2) selecting or developing supporting media, (3) developing guidelines for students, (4) developing guidelines for teachers, (5) conducting Formative Revisions, and (6) do a trial. The implementing phase aims to prepare the learning environment and involve students physically and mentally. The procedure performed at this implementation stage is preparing teachers and students. After completing the
Implementation phase, the developer must be able to move to an actual learning environment where students can begin to build new knowledge and skills needed to close the performance gap. The evaluation phase aims to determine the quality of products and processes before and after implementation or implementation. The procedures performed in connection with this evaluation stage are (1) determining evaluation criteria, (2) choosing an evaluation tool, and (3) conducting an evaluation.

Respondents involved in the process of developing eWS and conducting evaluations were teachers and students in SMA Negeri 1 Jambi City. Validation is carried out by two validators.

\section{Result and Discussion}

The analysis phase that has been done aims to identify the possible causes of performance gaps that occur in students. The results of the analysis are shown in Table 1.

Table 1. Performance Evaluation on Electromagnetic Induction Learning Design

\begin{tabular}{|c|c|c|c|}
\hline Current performance & Expected performance & The main cause & Performance Gaps \\
\hline $\begin{array}{l}30 \% \text { of students are able to analyze } \\
\text { the phenomenon of electromagnetic } \\
\text { induction in everyday life } \\
\text { (Lack of knowledge) }\end{array}$ & $\begin{array}{l}\text { Analyzing the } \\
\text { phenomenon of } \\
\text { electromagnetic induction } \\
\text { in everyday life }\end{array}$ & $\begin{array}{l}\text { Do not understand the concept of } \\
\text { electromagnetic induction on } \\
\text { various technology products that } \\
\text { use Faraday induction }\end{array}$ & $70 \%$ \\
\hline $\begin{array}{l}25 \% \text { conducted an experiment on } \\
\text { electromagnetic induction following } \\
\text { the presentation of the results } \\
\text { (Induction Potential, Lenz's Law, } \\
\text { and Utilization of Induction } \\
\text { potential). (Lack of skills) }\end{array}$ & $\begin{array}{l}\text { Conducting experiments } \\
\text { on electromagnetic } \\
\text { induction and the } \\
\text { presentation of results in } \\
\text { daily life }\end{array}$ & $\begin{array}{l}\text { Practicum equipment already } \\
\text { exists and has been equipped with } \\
\text { a trial guide. However, the } \\
\text { majority of students have not been } \\
\text { able to understand the guidelines. }\end{array}$ & $75 \%$ \\
\hline
\end{tabular}

Based on the results of the analysis, it is known that there are performance gaps, namely the lack of students' knowledge and skills. Therefore, instructional objectives can be formulated, namely "to teach students so that they have the competence of knowledge and skills on electromagnetic induction material". Then the students were analyzed, and data were obtained those (1) characteristics: the average age of students was 17 years with a range of 16-18 years. All students have the basic ability to use an Android-based computer or mobile device, (2) Number of students: students who are the target of learning are students who experience knowledge and skills problems. The implementation of learning in this study is aimed at all students (177 people), (3) preferences: students tend to be motivated if learning is done using media, and (4) level of experience: all students have studied Magnetic Induction (as a prerequisite). Based on these data, students' characteristics, experiences, and preferences can be identified as a basis for developing eWS. Furthermore, all types of resources needed are identified through observation and analysis of technology, facilities, and human resources related to the content or content of electromagnetic induction learning (Table 2).

The next stage of analysis is determining the delivery system so that the right choice of the delivery system for implementing the learning can be known (Table 3). 
Table 2. Resource Identification

\begin{tabular}{|c|c|c|c|}
\hline Content & Technology & Facility & Human Resources \\
\hline $\begin{array}{ll}\text { - } & \text { Induction GGL } \\
\text { - } & \text { Lenz's Law } \\
\text { - } & \text { Self-inductance } \\
\text { Applied } \\
\text { electromagnetic } \\
\text { induction in } \\
\text { technological } \\
\text { products }\end{array}$ & $\begin{array}{l}\text { - Computer equipment is } \\
\text { available at school. } \\
\text { Students also have } \\
\text { laptops and smartphones } \\
\text { that can be used. } \\
\text { - Available magnetic power } \\
\text { equipment }\end{array}$ & $\begin{array}{l}\text { - Laboratory rooms and classrooms can } \\
\text { be used for learning activities. } \\
\text { - Classrooms and laboratory capacities } \\
\text { are for } 40 \text { students. } \\
\text { - Classrooms and laboratories can be } \\
\text { used. } \\
\text { - Spatial use schedules can be arranged } \\
\text { according to learning needs. }\end{array}$ & $\begin{array}{l}\text { - There are two } \\
\text { physics teachers } \\
\text { who can help with } \\
\text { learning activities }\end{array}$ \\
\hline
\end{tabular}

Table 3. Determine Potential Delivery Systems

$\begin{array}{llll}\text { Step } 1 & & \text { Option A: } & \text { Face to face learning without an Electronic Worksheet } \\ \text { Identify potential delivery } & \text { Option B: } & \text { Face to face learning using an Interactive Electronic Worksheet }\end{array}$ system options

Step 2

Estimated time for each delivery system choice

Option A:

Option B:

Option A: More costs are required for printing Non-electronic Worksheets

Option B: It costs less because Electronic Worksheets can be shared.

Step 3

Estimated cost for each delivery system choice

Based on the data in Table 3 about determining the delivery system, it can be seen that the choice of face-toface learning using interactive electronic worksheets (option B) is better because it takes less time and costs.

At the design stage, an inventory of tasks is carried out, determining performance goals, and producing test strategies. The task inventory is carried out to identify the tasks required to achieve instructional objectives which include three types of tasks, namely cognitive tasks (related to electromagnetic induction knowledge), motor tasks (related to the skills that must be obtained in learning electromagnetic induction), and procedural tasks (related to the procedure or steps that must be carried out). Based on this stage, flowchart designs and interactive electronic worksheet designs are obtained. Figure 2 is an example of the primary process of eWS design.

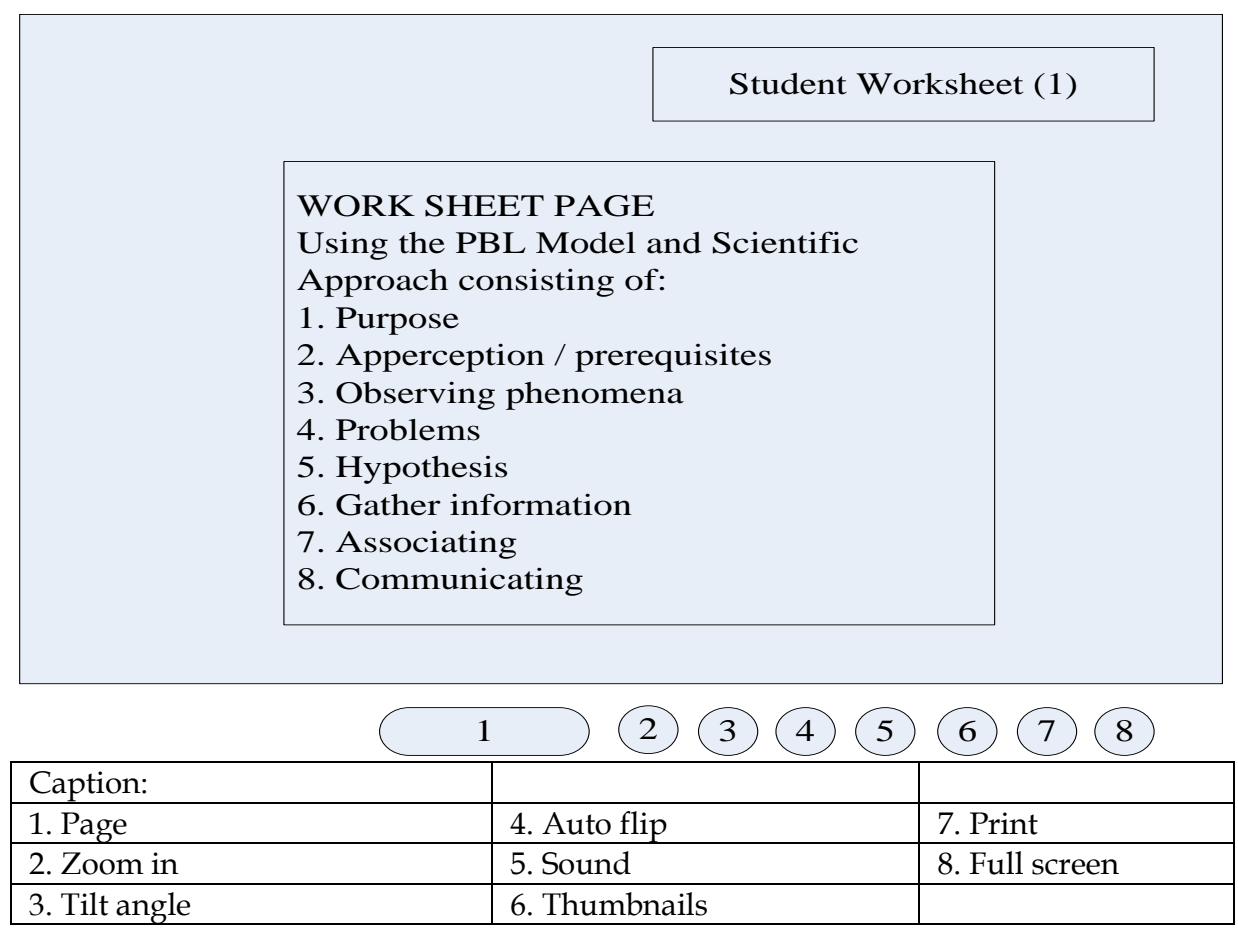

Figure 2. Flowchart design of Interactive electronic worksheets (eWS) 
At this stage also obtained the Storyboard design eWS title page and eWS worksheet design with a scientific approach. Furthermore, based on the design that has been developed, the development stage is carried out. Example of the results of this development stage are:

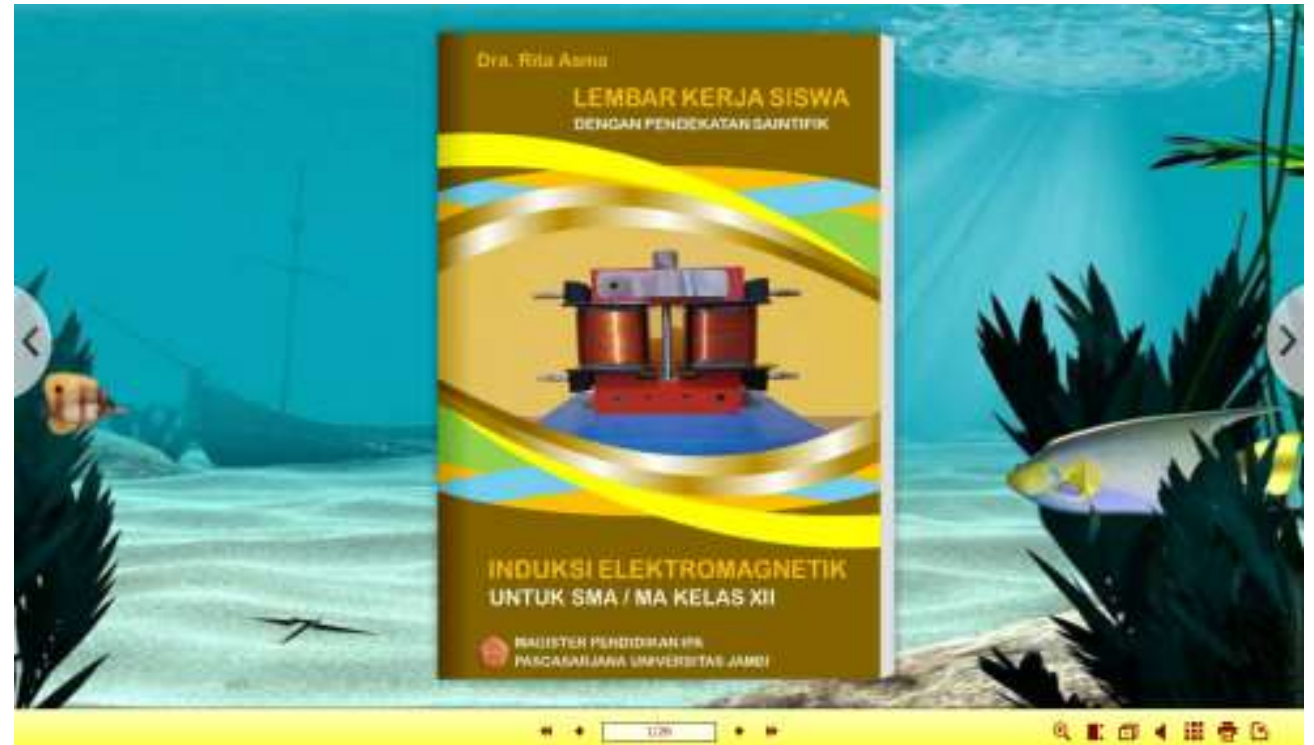

Figure 3. Initial view of electronic worksheets (eWS)

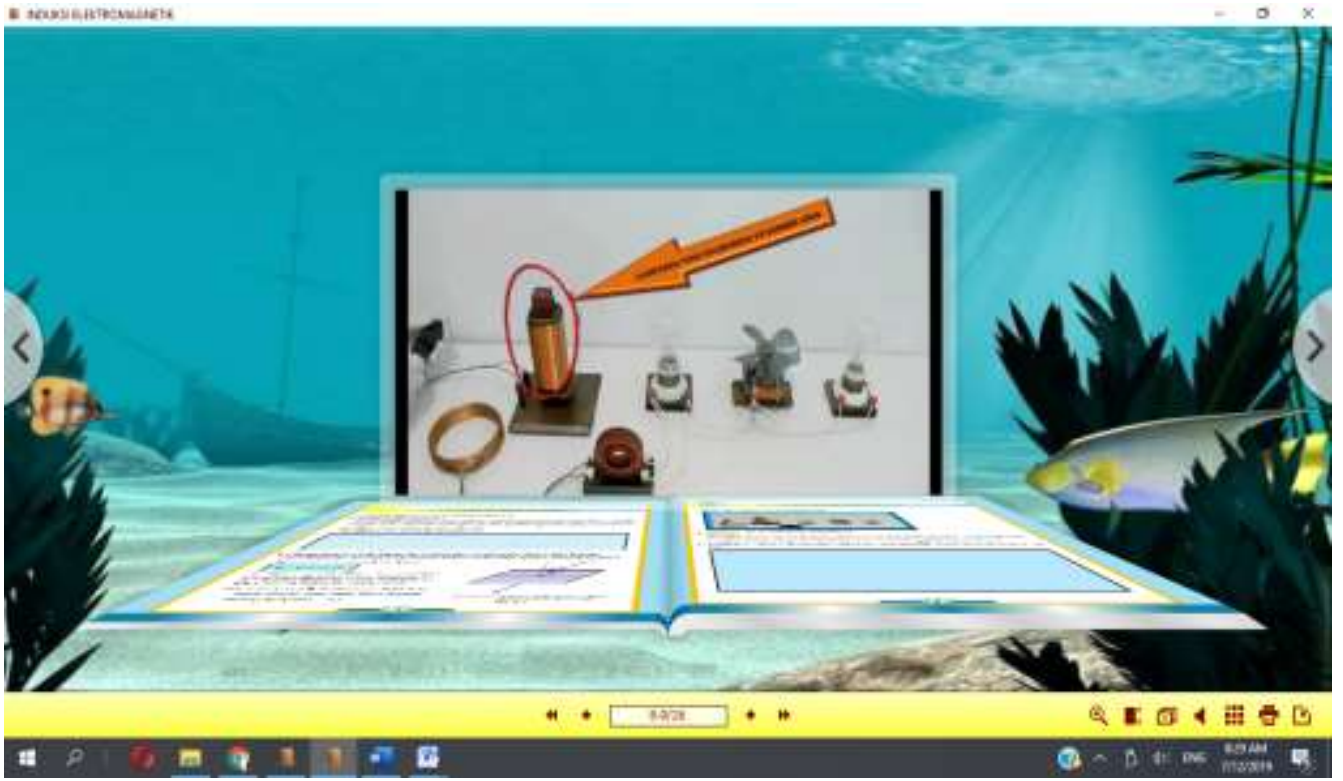

Figure 4. Display the video screenshot

During the development phase, a guide was also developed for students that contained information that was useful to add to the student's learning experience. With this guide, the eWS: (1) there is regularity in each part of the learning activities according to planning, (2) there is a logical sequence in each learning episode, (3) there is a smooth implementation of the learning strategy, and (4) there is harmony in the content sequence for students and content for teachers. During the development process, formative revisions were made to the eWS by involving media experts and material experts as validators. The results of the validator's final assessment of the validity of eWS products were analyzed using the Cohen's Kappa formula, namely:

(1) Material:

$$
\begin{aligned}
\operatorname{Kappa}(k) & =\frac{P-P E}{1-P \mathscr{E}} \\
& =\frac{1,0,00}{1-0,00} \\
& =1,00
\end{aligned}
$$

(2) Media: 


$$
\begin{aligned}
\operatorname{Kappa}(k)= & \frac{P-P e}{1-P e} \\
& =\frac{0,9-0,1}{1-0,11} \\
& =0,89
\end{aligned}
$$

Based on the kappa value, it was concluded that the developed eWS was categorized as valid for the material and the media and ready to be tested in small group trials and field trials, as shown in Figure 5.

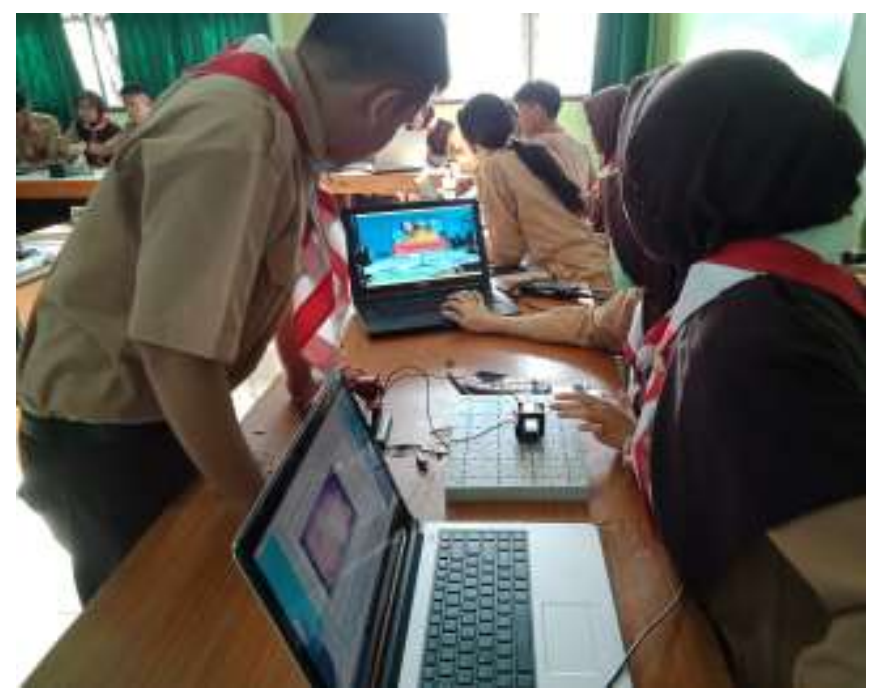

Figure 5. Implementation of field trials

Based on field trials on one class, information was obtained about student performance and the presentation system. Data collection is done by observation and dissemination of instruments. Observation results show that student performance is very good in the learning process using eWS. Students look very enthusiastic to participate actively in the learning process and all stages of the scientific approach that has been planned by students. In other words, the presentation system using eWS is very suitable in learning electromagnetic induction and can be continued at the implementation stage.

The process carried out at the implementation stage is preparing students, teaching materials, and learning tools. The learning process was carried out on 177 students of class XII. Each group of students uses a minimum of two laptops. The steps taken by the teacher are (1) preparing practicum tools, (2) introducing electromagnetic induction topics, (3) dividing students into seven groups (each group consists of 4 or 5 students), (4) providing electromagnetic induction eWS softcopy in exe format and practicum tools to students, (5) directing students to open electromagnetic induction eWS files, (6) observing students in using electromagnetic induction eWS and doing practicums, and (7) assisting students in presenting learning or discussion results. Evaluation Phase, this stage is carried out to determine the quality of the products that have been developed. There are two stages of conducting an evaluation, namely a Level 1 evaluation to measure students 'perceptions of eWS and a Level 2 evaluation to measure students' knowledge and skills achievements as well as to know the impact of using eWS.

\section{Level 1: Perception}

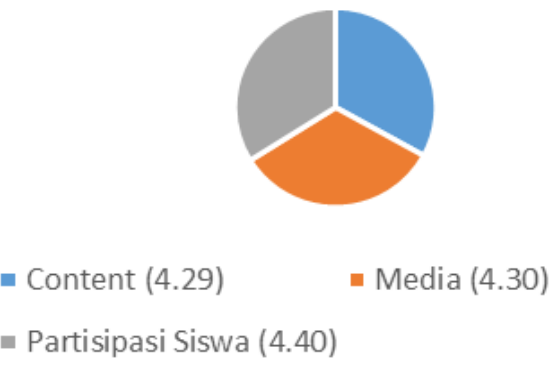

Figure 6. Level 1 evaluation results (students' perception of eWS)

The results of Level 1 evaluations using a questionnaire instrument show that students have a good perception of eWS content and media. Students also perceive that they are involved or participate in the learning process that uses eWS (Figure 6 and Figure 7). The average score obtained at each scale is 4.29 for $\mathrm{eW}$ content, 4.30 for media, and 4.40 for student participation in learning.

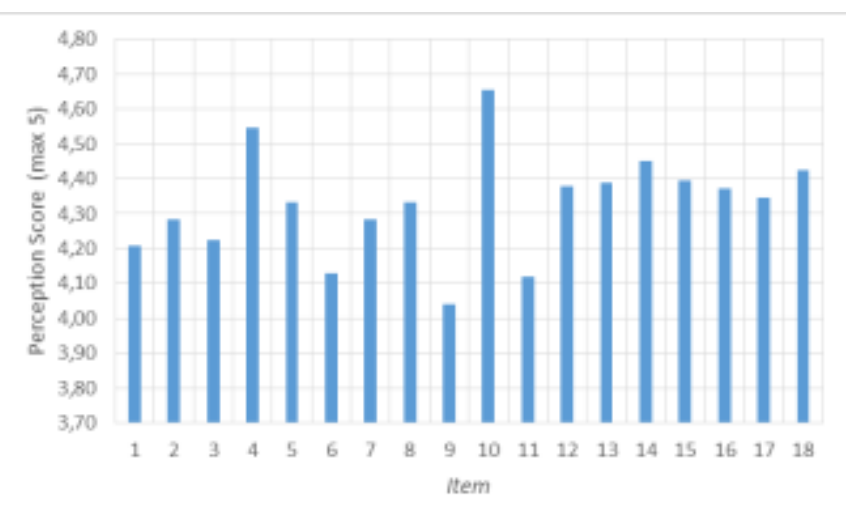

Figure 7. Detail of students' perceptions of eWS products

According to students, eWS can provide a new learning atmosphere (item 10). This finding is a very positive thing because a good atmosphere or learning environment will reduce the obstacles to achieving student competency through the learning process. This is in line with the findings of Maison, et al. (2019) that the achievement of student competencies is largely determined by the learning environment. In addition, according to students, interactive eWS helps them learn electromagnetic induction (items 1 and 2) and is also effectively used (item 18). The steps of the scientific 
approach that are the basis for the development and use of electromagnetic induction interactive eWS are also perceived as good by students. Students feel fit with the stage of the activity carried out (item 3), and eWS are able to involve students in participating in the learning process (items 13,16, and 17). The process of involving students in the learning process will certainly produce a conception (Gurel, et al., 2015) that is different from the conceptions obtained without student participation. Level 2 evaluation results using independent-sample t-test to compare the value of students who learn using eWS and who do not use eWS, show that there are significant score differences for learning with eWS $(\mathrm{M}=73.87, \mathrm{SD}=22.56)$ and learning not using eWS $(\mathrm{M}=27.73, \mathrm{SD}=15.51)$; $\mathrm{t}(54)=$ $10.51, \mathrm{p}=0.00$ (two-tailed). The difference in mean values that is equal to 46 ( $95 \%$ confidence level) is large (eta squared $=0.58$ ). Thus the use of eWS has an effect or impact on student learning outcomes. The findings of this study are in line with the findings of Hidayati et al. (2019) who developed a virtual worksheet on curvature and the findings of Hayati et al. (2015) who developed FlipBook physics as well as Nasir, et al. (2015) who conducted experimental research using the Generic Science Integrated Inquiry worksheet.

\section{Conclusion}

Based on the results of research and development of interactive Electronic Student Worksheets on electromagnetic induction material with a scientific approach using 3D Pageflip, Camtasia Studio 8, and Adobe Flash Professional CS6 can be concluded: 1) The development process carried out using the ADDIE model can be described simply according to research procedures, namely: (a) validating performance gaps, (b) determining instructional objectives, (c) conducting analysis or confirmation of students, (d) identifying the sources needed, I determining the delivery system, (f) preparing work plans, ( g) carry out an inventory of tasks, (h) set performance goals, (i) produce test strategies, (j) produce content, (k) media selection and development, and (l) guide development. 2) The electronic worksheet is categorized as suitable for use both in terms of the material and the media used. 3) The use of interactive electronic worksheet products on electromagnetic induction material with a scientific approach in the implementation phase gets a very positive response from students and is able to have a positive impact that is seen from the significant difference in learning outcomes shown by data from the t-test (independent-sample t-test).

\section{References}

Branch, R. M. (2009). Instructional Design: The ADDIE Approach. 233 Spring Street, New York: Springer Science+Business Media, LLC.

Doyan, A., Taufik, M., \& Anjani, R. (2018). Pengaruh pendekatan multi representasi terhadap hasil belajar fisika ditinjau dari motivasi belajar peserta didik. Jurnal Penelitian Pendidikan IPA (JPPIPA) JPPIPA), 4(1), 35-45.

Fatri, F. F., Maison, \& Syaiful. (2019). Kemampuan representasi matematis siswa Kelas VIII SMP ditinjau dari gaya kognitif visualizer dan verbalizer. Jurnal Didaktik Matematika, 6(2), 98-111. https://doi.org/10.24815/jdm.v\%vi\%i.14179

Gurel, D. K., Eryilmaz, A., \& McDermott, L. C. (2015). A review and comparison of diagnostic instruments to identify students' misconceptions in science. Eurasia Journal of Mathematics, Science and Technology Education, 11(5), 989-1008. https://doi.org/10.12973/eurasia.2015.1369a

Hayati, S., Budi, A. S., \& Handoko, E. (2015). Pengembangan media pembelajaran flipbook fisika untuk meningkatkan hasil belajar peserta didik. Prosiding Seminar Nasional Fisika (e-Jurnal) SNF2015, IV, 49-54.

Hidayati, H., \& Masril, M. (2019). Penggunaan LKM untuk menunjang kegiatan laboratorium virtual Fisika Inti. Jurnal Penelitian Pendidikan IPA, 5(2), 149-153.

https://doi.org/10.29303/jppipa.v5i2.250

Hidayati, Masril, Darvina, Y., \& Zakiya, Z. (2019). Efektivitas lembar kerja siswa virtual laboratory pada materi gerak lengkung di kelas X SMAN. Jurnal Eksakta Pendidikan, 3(1), 47-54.

Hidayatullah, M. S., \& Rakhmawati, L. (2016). Pengembangan media pembelajaran berbasis flip book maker pada mata pelajaran elektronika dasar di SMK Negeri 1 Sampang. Jurnal Pendidikan Teknik Elektro, 5(1), 83-88.

Khaira, I., Maison, \& Marzal, J. (2017). Pengembangan perangkat pembelajaran fisika berbasis virtual laboratorium pada materi listrik di SMK. EduSains, 6(2), 24-30.

Kurniawati, H., Desnita, D., \& Siswoyo, S. (2016). Pengembangan media pembelajaran berbasis 3D PageFlip fisika untuk materi getaran dan gelombang bunyi. Jurnal Penelitian $\mathcal{E}$ Pengembangan Pendidikan Fisika, 2(1), 97-102. https://doi.org/10.21009/1.02114

Maison, Astalini, Kurniawan, D. A., \& Sholihah, L. R. (2018). Deskripsi sikap siswa SMA negeri pada mata pelajaran fisika. EDUSAINS, 10(1), 160-167. https://doi.org/10.15408/es.v10i1.7214 
Maison, Darmaji, Astalini, Kurniawan, D. A., \& Indrawati, P. S. (2019). Science process skills and motivation. Humanities $\mathcal{E}$ Social Sciences Reviews, $7(5)$, 48-56. https://doi.org/10.18510/hssr.2019.756

Maison, Lestari, N., \& Widaningtyas, A. (2020). Identifikasi miskonsepsi siswa pada materi usaha dan energi. $6(1)$, 32-39. https://doi.org/10.29303/jppipa.v6i1.314

Maison, M., Syahrial, Syamsurizal, \& Tanti. (2019). Learning environment, students' beliefs, and selfregulation in learning physics: Structural equation modeling. Journal of Baltic Science Education, 18(3), 389-403. https://doi.org/10.33225/jbse/19.18.389

Mayasari, H., Syamsurizal, \& Maison. (2015). Pengembangan lembar kerja siswa (LKS) berbasis karakter melalui pendekatan saintifik pada materi fluida statik untuk Sekolah Menengah Atas. EduSains, 4(2), 30-36.

Nasir, M., Harjono, A., \& Sridana, N. (2015). Pengaruh Pembelajaran Menggunakkan LKS Inkuiri Terintegrasi Generik Sains (ITGS) terhadap Hasil Belajar Fisika Ditinjau dari Motivasi Berprestasi Siswa di SMAN 1 Aikmel. 1(1), 78-90.

Oon, P. T., \& Subramaniam, R. (2011). On the declining interest in physics among students-from the perspective of teachers. International Journal of Science Education, 33(5), 727-746. https://doi.org/10.1080/09500693.2010.500338

Utama, Z. P., Maison, \& Syarkowi, A. (2018). Analisis kemampuan bernalar siswa SMA Kota Jambi. Jurnal Penelitian Pembelajaran Fisika, 9(1), 1-5. https://doi.org/10.26877/jp2f.v9i1.2223 